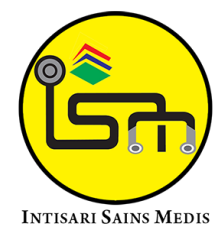

Published by Intisari Sains Medis

\section{Perbandingan efektivitas dan keamanan antara roxadustat dan epoetin alfa sebagai terapi anemia pada pasien yang menjalani hemodialisis reguler: meta analisis}

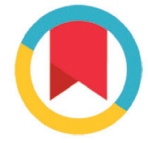

CrossMark

Pubished by Intisari Sains Medis

\author{
Kadek Wisnu Segara Karya ${ }^{1 *}$, Ni Luh Parameswari Praptika ${ }^{2}$, \\ Nyoman Yudia Trianadewi Nurbudhi ${ }^{2}$, Yenny Kandarini ${ }^{3}$
}

\begin{abstract}
Introduction: Chronic kidney disease (CKD) is a global health problem. Hemodialysis (HD) is one of the treatment modalities for end-stage renal disease which is commonly used. A complication that is often found in patients undergoing regular $H D$ is anemia. Roxadustat is a prolyl hydroxylase inhibitor (PHI) which has a potential as an alternative therapy for anemia in patients undergoing regular $\mathrm{HD}$. The aim of this metaanalysis was to compare the efficacy and safety of roxadustat and epoetin alfa as anemia management in patients undergoing regular $\mathrm{HD}$.

Methods: We searched the literature sources in the PubMed, MEDLINE, Cochrane, Scopus, Embase, Elsevier, and Proquest databases until June 1, 2021. The search terms used were chronic kidney disease, hemodialysis, dialysis, roxadustat, epoetin alfa, anemia management, incidence of side effects, randomize, and randomization. We excluded the study population with

acute kidney injury/dyslipidemia/metabolic syndrome. All analyzes in this meta-analysis were performed using Review Manager version 5.3 (RevMan Cochrane, London, UK).

Result: We have found five eligible studies (2777 patients). Funnel plots and p-Egger were examined to assess publication bias. The results showed a statistically significant difference between roxadustat and epoetin alfa with respect to the mean difference of hemoglobin (Hb) (WMD: $0.31 ; p<0.05$ ), hepcidin (WMD: -18.94; $p<0.05$ ), transferrin (WMD: 67.88; $p<0.05$ ), transferrin saturation (WMD: $2.78 ; p<0.05$ ), iron (WMD: $5.02 ; p<0.05$ ) and risk of adverse events (OR: $1.25 ; \mathrm{p}<0.05$ ) displayed on the forest plot.

Conclusion: Based on this meta-analysis, it can be concluded that anemia management with roxadustat is better than epoetin alfa in patients undergoing regular HD.
\end{abstract}

Keywords: Chronic kidney disease, hemodialysis, anemia management, roxadustat, epoetin alfa.

Cite This Article: Karya, K.W.S., Praptika, N.L.P., Nurbudhi, N.Y.T., Kandarini, Y. 2021. Perbandingan efektivitas dan keamanan antara roxadustat dan epoetin alfa sebagai terapi anemia pada pasien yang menjalani hemodialisis reguler: meta analisis. Intisari Sains Medis 12(3): 768-776. D0I: 10.15562/ism.v12i3.1130

\section{ABSTRAK}

'Rumah Sakit Bhayangkara, Denpasar, Bali; ${ }^{2}$ Fakultas Kedokteran, Universitas Udayana, Denpasar, Bali;

${ }^{3}$ Departemen Ilmu Penyakit Dalam, Fakultas Kedokteran, Universitas Udayana, Denpasar, Bali

\section{*Korespondensi:}

Kadek Wisnu Segara Karya;

Rumah Sakit Bhayangkara, Denpasar, Bali; wisnuverbind@gmail.com
Latar Belakang: Penyakit ginjal kronis (PGK) merupakan masalah kesehatan global. Hemodialisis (HD) merupakan salah satu modalitas terapi PGK stadium akhir yang umum digunakan. Komplikasi yang sering ditemukan pada pasien yang menjalani HD reguler adalah anemia. Roxadustat adalah suatu prolyl hydroxylase inhibitor (PHI) yang memiliki potensi sebagai alternatif terapi anemia pada pasien yang menjalani HD reguler. Tujuan dari meta-analisis ini adalah untuk membandingkan efektivitas dan keamanan antara roxadustat dan epoetin alfa sebagai manajemen anemia pada pasien yang menjalani HD reguler.

Metode: Kami mencari sumber literatur pada database PubMed, MEDLINE, Cochrane, Scopus, Embase, Elsevier, dan Proquest hingga 1 Juni 2021. Istilah pencarian yang digunakan yaitu penyakit ginjal kronis, hemodialisis, dialisis, roxadustat, epoetin alfa, manajemen anemia, kejadian efek samping, acak, dan pengacakan. Kami mengeksklusi populasi penelitian dengan cedera ginjal akut/dislipidemia/sindrom metabolik. Semua analisis dalam meta-analisis ini dilaksanakan dengan menggunakan Review Manager versi 5.3 (RevMan Cochrane, London, UK).

Hasil: Kami menemukan lima studi yang memenuhi syarat (2777 pasien). Funnel plot dan p-Egger diperiksa untuk menilai bias publikasi. Hasil menunjukkan perbedaan signifikan secara statistik antara roxadustat dan epoetin alfa terhadap perbedaan rerata dari hemoglobin $(\mathrm{Hb})$ (WMD: 0,$31 ; \mathrm{p}<0,05)$, hepsidin 
(WMD: $-18,94 ; p<0,05)$, transferin (WMD: 67,88; $p<0,05$ ), saturasi transferin (WMD: 2,78; $p<0,05$ ), zat besi (WMD: 5,$02 ; \mathrm{p}<0,05$ ) dan risiko kejadian efek samping (OR: 1,$25 ; p<0,05)$ yang ditampilkan pada forest plot.
Kesimpulan: Berdasarkan meta-analisis ini, dapat disimpulkan bahwa manajemen anemia dengan roxadustat lebih baik dibandingkan dengan epoetin alfa pada pasien yang menjalani HD reguler.

Kata kunci: Penyakit ginjal kronis, hemodialisis, manajemen anemia, roxadustat, epoetin alfa.

Sitasi Artikel ini: Karya, K.W.S., Praptika, N.L.P., Nurbudhi, N.Y.T., Kandarini, Y. 2021. Perbandingan efektivitas dan keamanan antara roxadustat dan epoetin alfa sebagai terapi anemia pada pasien yang menjalani hemodialisis reguler: meta analisis. Intisari Sains Medis 12(3): 768-776. D0I: 10.15562/ism.v12i3.1130

\section{PENDAHULUAN}

Penyakit ginjal kronis (PGK) adalah masalah kesehatan global yang mempengaruhi lebih dari $10 \%$ populasi di negara - negara industri. ${ }^{1}$ Pada negara negara berkembang, sekitar 30\% individu berusia di atas 65 tahun menderita PGK stadium 3-5., ${ }^{2,3}$ Hemodialisis (HD) merupakan salah satu modalitas terapi PGK stadium akhir yang umum digunakan. Komplikasi yang sering ditemukan pada pasien yang menjalani HD reguler adalah anemia. ${ }^{4}$ Sebuah studi melaporkan bahwa anemia terjadi pada 80$90 \%$ pasien yang menjalani HD reguler. ${ }^{5}$ Penelitian lainnya menunjukkan bahwa penurunan fungsi ginjal berhubungan signifikan dengan kejadian anemia. ${ }^{6,7}$ Anemia pada pasien yang menjalani HD reguler akan berdampak pada memburuknya fungsi kognitif, kesehatan fisik maupun mental, kualitas hidup, peningkatan morbiditas dan mortalitas kardiovaskular, serta meningkatkan biaya dan lama rawat inap..$^{8-11}$ Penentuan terapi yang tepat dalam tatalaksana anemia pada pasien yang menjalani HD reguler dapat mengurangi angka kesakitan, mortalitas, meningkatkan kualitas hidup, serta memperbaiki prognosis. ${ }^{8}$ Berdasarkan Kidney Disease: Improving Global Outcomes (KDIGO), terapi yang umumnya diberikan pada pasien yang menjalani HD reguler dengan anemia antara lain terapi besi, Erythropoetin Stimulating Agent (ESA) dan transfusi darah. ${ }^{12}$ Salah satu golongan ESA yang umum digunakan adalah eritropoietin alfa atau yang lebih dikenal dengan istilah epoetin alfa. Sebelum ketersediaan ESA, anemia berat pada pasien yang menjalani HD reguler diterapi dengan transfusi darah secara berulang. Efek samping transfusi darah yang dapat terjadi yaitu allosensitization, dimana kondisi ini dapat mengganggu keberhasilan dalam proses transplantasi ginjal. Penggunaan ESA dapat mengurangi efek samping dari transfusi darah tersebut. ${ }^{13}$

Pada studi the Correction of Hemoglobin and Outcomes in Renal Insufficiency (CHOIR), studi Normal Hematocrit Cardiac Trial (NHCT), studi the Trial to Reduce Cardiovascular Events With Aranesp Therapy (TREAT), serta studi the Cardiovascular Risk Reduction by Early Anemia Treatment With Epoetin Beta (CREATE), ${ }^{14-17}$ melaporkan efek samping penggunaan ESA dengan target nilai $\mathrm{Hb}>11 \mathrm{~g} / \mathrm{dL}$, menunjukkan peningkatan risiko kardiovaskular pada pasien yang menjalani HD reguler. ${ }^{14,15,17}$ Peningkatan risiko ini berkaitan dengan peningkatan dosis ESA dalam mencapai target $\mathrm{Hb}$ yang lebih tinggi. ${ }^{18,19}$ Keadaan ini menyebabkan adanya panduan penggunaan dosis ESA seminimal mungkin dalam mencapai kadar $\mathrm{Hb}$ optimal. ${ }^{20,21}$

Patogenesis anemia bersifat multifaktorial, salah satunya disebabkan oleh gangguan regulasi eritropoiesis yang dipengaruhi oleh kadar oksigen darah, faktor inflamasi, serta keadaan defisiensi besi. ${ }^{20,22,23}$ Hypoxia-Inducible Factor (HIF) merupakan faktor transkripsi yang berperan sebagai sensor utama tubuh terhadap tekanan oksigen yang dapat memediasi respons $\mathrm{Hb}^{24}$ Tingkat HIF diatur oleh enzim prolyl-hydroxylase sesuai besarnya tekanan oksigen. ${ }^{25}$ Ketika kadar oksigen menurun (hipoksia), aktivitas enzim prolyl-hydroxylase juga akan menurun, sehingga terjadi akumulasi subunit HIF- $\alpha$ dan peningkatan aktivitas transkripsi HIF. Faktor ini akan menginduksi ekspresi eritropoietin, reseptor eritropoetin, dan protein yang akan merangsang penyerapan besi di usus serta meningkatkan penyimpanan besi pada makrofag. ${ }^{26}$ Berbagai studi telah membahas mengenai terapi anemia pada pasien yang menjalani HD reguler dengan memanfaatkan fisiologi alami regulasi eritropoiesis, salah satunya melalui regulasi HIF. ${ }^{27-29,30}$

Roxadustat merupakan prolylhydroxylase inhibitor (PHI) yang kuat serta bersifat reversibel dalam menghambat dan mencegah degradasi hidroksilasi HIF- $\alpha$. HIF- $\alpha$ berdimerisasi dengan HIF- $\beta$ dan menginduksi ekspresi eritropoietin. Roxadustat dapat meniru respons alami tubuh terhadap hipoksia untuk meningkatkan produksi sel darah merah dalam kondisi normoksia pada pasien anemia. ${ }^{25}$ Berbagai penelitian terdahulu telah menilai efektifitas roxadustat sebagai terapi anemia pada pasien yang menjalani HD reguler. ${ }^{31-33}$ Sebuah penelitian mengenai pengobatan anemia pada pasien yang menjalani HD reguler, melaporkan pengobatan roxadustat menghasilkan peningkatan kadar $\mathrm{Hb}$ maksimum sebesar $3,1 \pm 0,2 \mathrm{~g} / \mathrm{dL}$ selama 12 minggu pengobatan. ${ }^{34}$ Roxadustat dalam pengobatan anemia pada pasien yang menjalani HD reguler menghasilkan pemeliharaan efek terapeutik dalam jangka waktu yang lama, tanpa efek samping yang bermakna pada sistem HIF. ${ }^{35-37}$ Berdasarkan paparan latar belakang tersebut, kajian meta-analisis ini bertujuan untuk membandingkan efektivitas dan keamanan antara roxadustat dan epoetin alfa sebagai manajemen anemia pada pasien yang menjalani HD reguler. 


\section{METODE}

\section{Kriteria Inklusi, Sumber Data, dan Protokol Pencarian Studi}

Kami mencari sumber literatur pada database PubMed, MEDLINE, Cochrane, Scopus, Embase, Elsevier, dan Proquest hingga 1 Juni 2021. Kombinasi kata kunci berikut dalam bahasa Inggris (English) digunakan dalam pencarian literatur: "chronic kidney disease, hemodialysis, dialysis, roxadustat, epoetin alfa, anemia management, incidence of side effects, randomize, and randomization". Studi yang dipertimbangkan untuk digunakan ke dalam studi ini yaitu telah memenuhi kriteria sebagaiberikut: desain Randomized Control Trial (RCT), manajemen anemia dengan menggunakan roxadustat atau epoetin alfa yang ditetapkan secara acak, dan populasi pasien yang menjalani HD reguler. RCT dieksklusi jika judul/ abstrak tidak sesuai, publikasi duplikat, dan populasi dengan cedera ginjal akut/ dislipidemia/sindrom metabolik. Diagram alur meta-analisis ini diilustrasikan pada
Gambar 1.

\section{Seleksi Studi dan Penilaian Kualitas}

Kami menilai risiko bias dari beberapa komponen, yaitu berdasarkan pada (1) prosedur randomisasi, (2) penyamaran alokasi, (3) penyamaran modalitas dari peserta, personel dan observer, (4) penyamaran saat evaluasi luaran, (5) pelaporan data hasil yang tidak lengkap, (6) pelaporan hasil yang selektif, dan (7) sumber bias lainnya.

\section{Pengumpulan Data dan Analisis Statistik}

Setelah kami memperoleh studi yang sesuai untuk digunakan, selanjutnya kami melakukan penghitungan dan mencatat data yang akan digunakan dalam analisis. Luaran akhir dan ukuran efek klinis dinilai berdasarkan hasil weighted mean difference (WMD). Jika memungkinkan, kami menghubungi penulis studi terkait, apabila dalam pengumpulan data, masih terdapat data yang tidak lengkap atau belum dicantumkan pada artikel yang

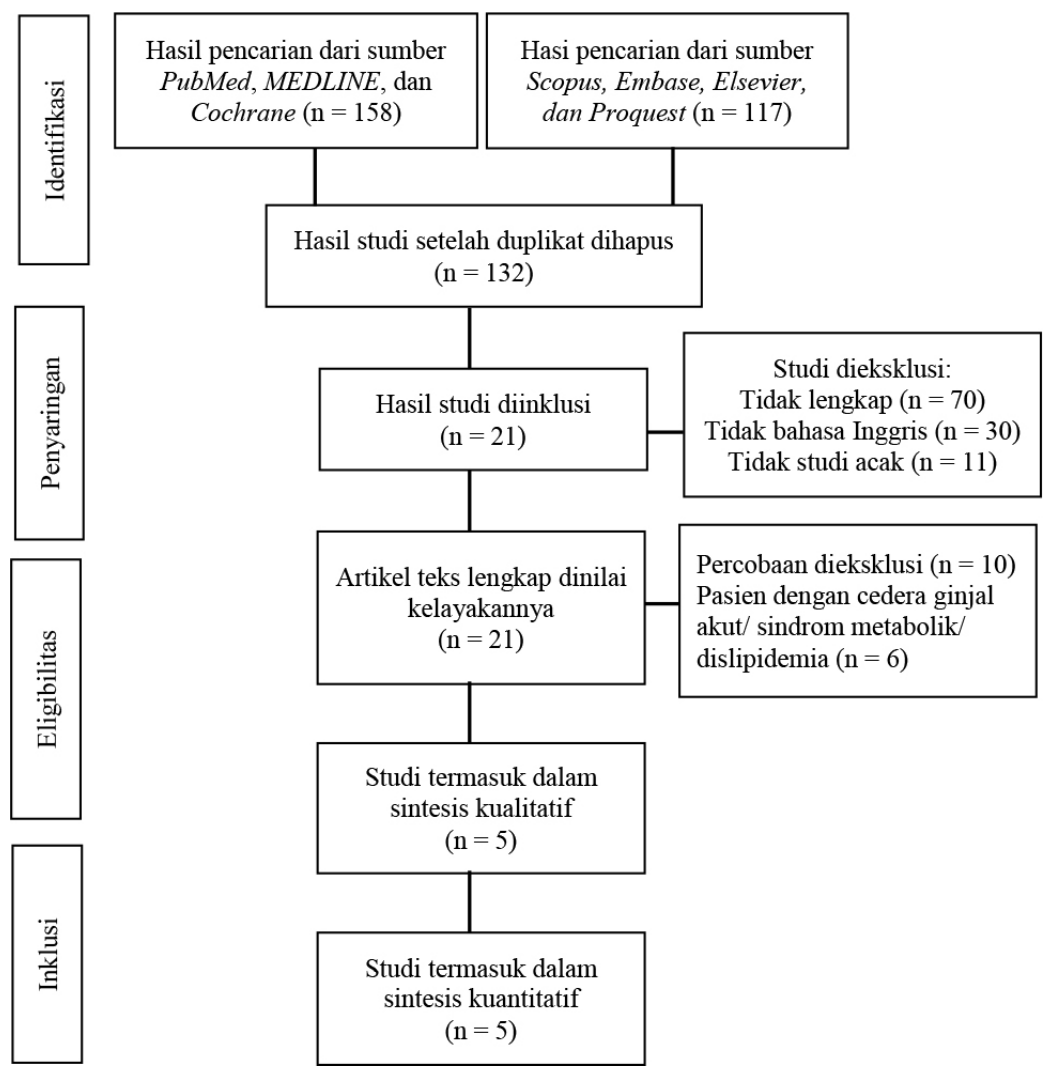

Gambar 1. Kualitas pelaporan diagram alur dalam meta-analisis ini. terpublikasi. Analisis akan difokuskan untuk membandingkan kadar $\mathrm{Hb}$, hepsidin, transferin, feritin, TIBC (Total Iron Binding Capacity), saturasi transferin, zat besi, dan kejadian efek samping pada pasien yang menjalani HD reguler dengan terapi roxadustat atau epoetin alfa, yang merujuk dalam pedoman Cochrane. ${ }^{38}$

Kami menggunakan model efek acak (random effect model) untuk mengevaluasi efek keseluruhan (overall effect). Pada penilaian heterogenitas, jika $p$-value $<0,10$ dianggap menggunakan model randomeffect, sedangkan jika heterogenitas tidak ditemukan maka digunakan model fixedeffect. Funnel Plot diperiksa secara visual, uji Egger digunakan untuk menguji bias publikasi dengan p-value $<0,05$ dianggap signifikan akan adanya bias publikasi. Semua analisis dalam penelitian meta-analisis ini dilakukan dengan menggunakan Review Manager versi 5.3 (RevMan Cochrane, London, UK).

\section{HASIL}

\section{Hasil Seleksi dan Karakteristik Studi}

Kami mengidentifikasi 275 studi dari pencarian dengan kata kunci dan memperoleh 21 studi yang relevan. Kami menemukan 5 RCT dengan 2777 pasien yang diterapi dengan roxadustat atau epoetin alfa (Gambar 1). Follow-up terhadap pasien dari masing-masing studi bervariasi antara 5 sampai 52 minggu dan ditentukan oleh target terapi berupa $\mathrm{Hb}$, hepsidin, transferin, feritin, TIBC, saturasi transferin, zat besi dan kejadian efek samping. Karakteristik yang digunakan dalam setiap penelitian dirangkum dalam Tabel 1. Hasil risiko bias dalam setiap penelitian tersedia pada Gambar 2.

Selain penilaian risiko bias publikasi di atas, kami juga menilai bias menggunakan uji funnel plot. Secara visual, funnel plot (Gambar 3) menunjukan sebaran kelima publikasi simetris, dan ini menunjukkan hasil penelitian memiliki bias publikasi yang rendah (Gambar 3).

\section{Perbandingan Efek Manajemen Anemia antara Roxadustat dan Epoetin Alfa pada Pasien yang Menjalani HD Reguler}

Forest plot pada Gambar 4a, 4c dan 4e menggunakan analisis model randomeffects, karena nilai $p$ lebih rendah dari 
Tabel 1. Kelayakan Studi dan Karakteristik Dasar Sampel.

\begin{tabular}{|c|c|c|c|c|c|c|c|c|c|c|c|c|}
\hline \multirow[t]{2}{*}{ Penelitian } & \multirow[t]{2}{*}{ Indikasi } & \multicolumn{2}{|c|}{ Pasien, $\mathbf{n}$} & \multicolumn{2}{|c|}{ Umur, tahun } & \multicolumn{2}{|c|}{ Laki-laki, n } & \multicolumn{2}{|c|}{$\begin{array}{c}\text { Lama HD, } \\
\text { tahun }\end{array}$} & \multicolumn{2}{|c|}{$\begin{array}{c}\text { Intervensi, dosis } \\
\text { (mg, mg/KgBB, IU/ } \\
\text { kgBB) }\end{array}$} & \multirow[t]{2}{*}{$\begin{array}{c}\text { Durasi Studi, } \\
\text { minggu }\end{array}$} \\
\hline & & $\mathbf{R}$ & $\mathbf{E}$ & $\mathbf{R}$ & $\mathbf{E}$ & $\mathbf{R}$ & $\mathbf{E}$ & $\mathbf{R}$ & $\mathbf{E}$ & $\mathbf{R}$ & $\mathbf{E}$ & \\
\hline Provenzano et al. 2016 & PGK & 108 & 36 & $\begin{array}{c}20- \\
80\end{array}$ & $\begin{array}{c}29- \\
78\end{array}$ & 72 & 23 & Nil & Nil & $70-200$ & $25-150$ & $6-19$ \\
\hline Chen et al. 2017 & PGK & 96 & 22 & 50 & 53 & 58 & 13 & Nil & Nil & $1,1-2,3$ & $85-150$ & $5-6$ \\
\hline Chen et al. 2019 & PGK & 204 & 100 & 47 & 51 & 126 & 58 & 4,5 & 4,4 & $100-120$ & $150-200$ & 26 \\
\hline Charytan et al. 2021 & PGK & 370 & 371 & 57 & 58 & 187 & 215 & 4 & 3,9 & 150 & 150 & $28-52$ \\
\hline Provenzano et al. 2021 & PGK & 760 & 770 & 53 & 54 & 461 & 464 & 2,3 & 2,3 & $70-150$ & $70-150$ & $28-52$ \\
\hline
\end{tabular}

Singkatan: R, roxadustat; E, epoetin alfa; PGK, penyakit ginjal kronis, HD, hemodialisis



Gambar 2. Ringkasan risiko bias: tinjauan penilaian peneliti terhadap risiko bias untuk setiap studi yang disertakan.

0,10 pada uji heterogenitas. Hasil overall effect yang diperoleh menunjukan adanya perbedaan signifikan pada rerata kadar $\mathrm{Hb}$ dan kadar transferin setelah mendapat terapi roxadustat dibandingkan epoetin alfa, dengan WMD sebesar 0,31 (IK95\% 0,08-0,53) dan 67,88 (IK95\% 29,86-105,90). Namun, tidak diperoleh perbedaan yang signifikan pada TIBC antara roxadustat dan epoetin alfa $(\mathrm{P}=0,10)$. Pada Gambar 4b, 4d, 4f dan 4g menggunakan analisis model fixed-effects, karena nilai $p$ lebih tinggi dari 0,10 pada uji heterogenitas. Hasil overall effect yang diperoleh menunjukan adanya perbedaan signifikan pada rerata kadar hepsidin, saturasi transferin, dan besi serum setelah mendapat terapi roxadustat dibandingkan epoetin alfa, dengan WMD sebesar -18,94 (IK95\% -35,28- -2,60); 2,78 (IK95\% $1,24-4,32)$; dan $5,02 \quad$ (IK95\% 3,65$6,40)$. Namun, tidak ditemukan adanya perbedaan signifikan pada rerata kadar feritin antara roxadustat dan epoetin alfa
$(\mathrm{P}=0,94)$.

Perbandingan Kejadian Efek Samping antara Roxadustat dan Epoetin Alfa pada Pasien yang Menjalani HD Reguler

Pada forest plot yang tersedia pada Gambar 5 menunjukkan bahwa analisis model fixed-effects digunakan karena nilai $p$ lebih tinggi dari 0,10 pada uji heterogenitas $\left(\mathrm{I}^{2}=\right.$ 25\%; $\mathrm{X} 2=34,79 ; \quad \mathrm{P}=0,12$ ). Berdasarkan pada hasil yang diperoleh, peningkatan kejadian efek samping pada roxadustat dibandingkan epoetin alfa berupa terjadinya infeksi dan gangguan pada saluran cerna. Peningkatan risiko sebesar 1,41 (IK95\% 1,09-1,81) dan 1,70 (IK95\% 1,22-2,35). Namun, tidak diperoleh perbedaan risiko kedua terapi terhadap kejadian efek samping lain seperti gangguan pada jantung, neurologis, muskuloskeletal, metabolik dan nutrisi serta gangguan pada lebih dari satu sistem organ. Pada hasil uji keseluruhan subgrup kejadian efek samping masing-masing terapi, diperoleh temuan kejadian efek samping secara statistik lebih tinggi pada terapi roxadustat dibandingkan dengan epoetin alfa dengan Odds Ratio/OR=1,25 (95\% CI: 1,13-1,38; $\mathrm{P}=0,0001$ ).

\section{PEMBAHASAN}

\section{Perbandingan Kadar Hepsidin}

Berdasarkan penelitian uji coba fase 3 menemukan rata-rata tingkat hepsidin sebelum diberikan terapi adalah $180,7 \pm 136,8 \mathrm{ng} / \mathrm{ml}$ pada kelompok roxadustat dan $148,3 \pm 104,2 \mathrm{ng} / \mathrm{ml}$ pada kelompok epoetin alfa. Pada penelitian lainnya menunjukkan adanya penurunan 


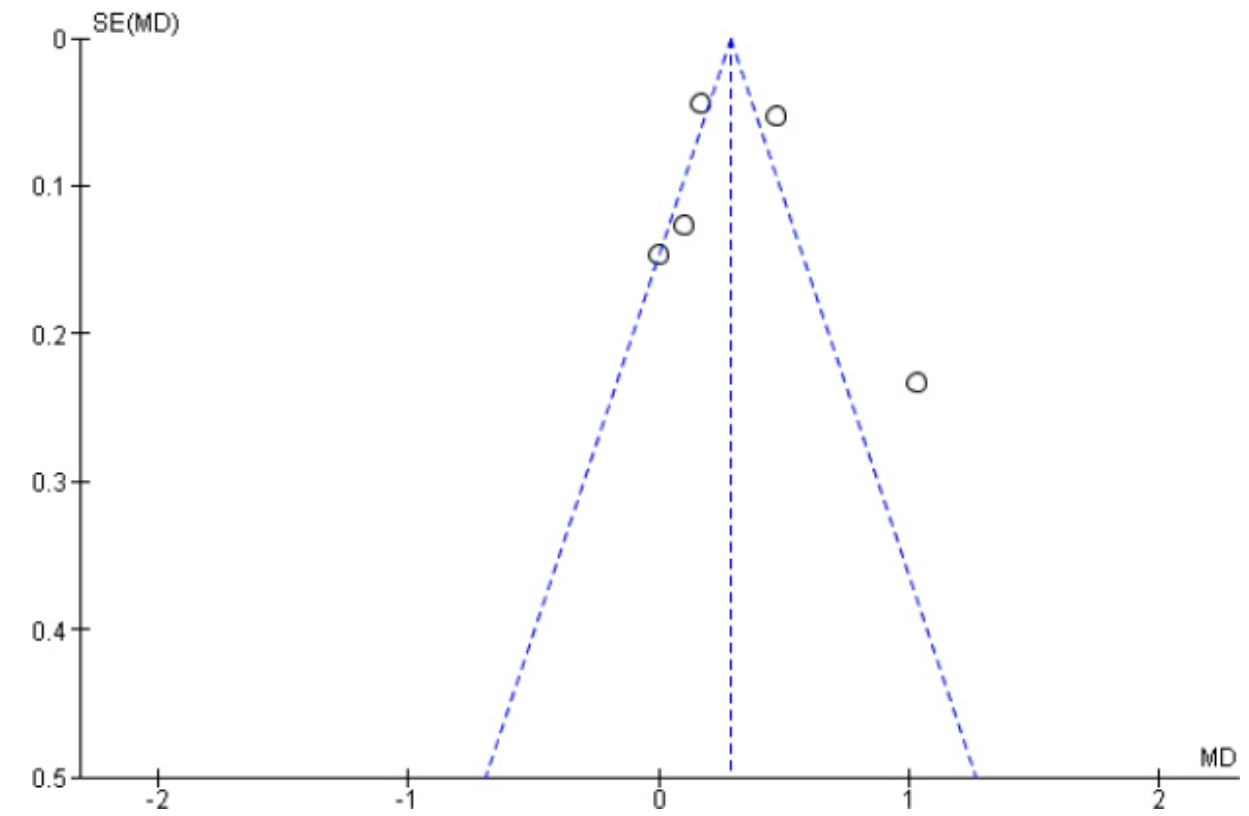

Gambar 3. Funnel plot manajemen anemia antara roxadustat dan epoetin alfa pada pasien gagal ginjal kronis yang menjalani HD.

kadar hepsidin di akhir minggu ke19 pengobatan dengan roxadustat. Perbedaan signifikan ditemukan pada rata-rata penurunan kadar hepsidin di kedua kelompok pengobatan $(\mathrm{P}=0,04)$, dimana pada pengobatan roxadustat rata-rata penurunan kadar hepsidin sebesar 60,4 $\pm 187,8 \mathrm{ng} / \mathrm{mL}$, sedangkan pada pengobatan epoetin alfa hanya sebesar 35,6 $\pm 123,4$ ng/mL. ${ }^{39,40}$ Penurunan hepsidin yang lebih besar pada kelompok roxadustat ini bertahan hingga minggu ke 52 pengobatan. ${ }^{42}$ Tiga penelitian lainnya juga menemukan hasil yang sejalan, sehingga dapat disimpulkan bahwa kadar hepsidin mengalami penurunan lebih banyak pada kelompok terapi roxadustat. ${ }^{33,39-42}$

Pada studi meta-analisis ini, kami memperoleh adanya perbedaan penurunan hepsidin signifikan secara statistik pada grup roxadustat (WMD18,94; 95\% IK: $-35,28$ - -2,60; $\mathrm{P}=0,02$ ). Penelitian meta-analisis lainnya juga melaporkan perbedaan penurunan kadar hepsidin yang signifikan pada pengobatan dengan roxadustat dibandingkan dengan pengobatan ESA (standard mean difference /SMD) -1,72; 95\% IK $-3,03 \quad-\quad-0,41$; $\mathrm{p}=0,01) .{ }^{43}$ Hasil temuan ini juga diperkuat dengan temuan lainnya yang melaporkan penurunan kadar hepsidin yang signifikan pada terapi roxadustat (SMD -4.46; 95\%
IK 5.02 - 3.89; $\mathrm{P}<0.00001) .{ }^{44}$

Berdasarkan analisis penelitian ini, ditemukan bahwa secara signifikan roxadustat dapat mengurangi kadar hepsidin pada pasien yang menjalani HD reguler. Hepsidin merupakan regulator utama dalam metabolisme zat besi. Peningkatan kadar hepsidin umumnya ditemukan pada pasien ESRD serta pasien dengan peradangan. Hepsidin mengurangi penyerapan zat besi di duodenum dan menghambat pelepasan zat besi yang tersimpan di jaringan, sehingga dapat mengganggu respon eritropoietin. ${ }^{27-29,40,45,46}$

\section{Perbandingan Kadar Besi Serum, Transferin, Saturasi Transferin, TIBC, dan Feritin}

Sebuah studi uji coba tahap 3, ditemukan rata-rata kadar besi serum pada kelompok roxadustat adalah $67,09 \pm 22,36 \mathrm{~g} / \mathrm{dl}$ dan $67,31 \pm 21,59 \mathrm{~g} / \mathrm{dl}$ pada kelompok epoetin alfa. Setelah minggu ke-4 pengobatan, didapatkan kadar besi serum relatif stabil pada kedua kelompok pengobatan, namun kadar besi serum secara signifikan lebih tinggi pada kelompok roxadustat dibandingkan epoetin alfa. Perubahan rata-rata dari kadar besi serum awal pengobatan yaitu $6,95 \pm 32,47$ pada kelompok roxadustat dan $0,35 \pm 28,81$ pada kelompok epoetin alfa (95\% IK:
2,20, 10,45; $\mathrm{P}=0,003) .{ }^{42}$ Penelitian serupa juga melaporkan bahwa pasien yang menjalani HD reguler yang menerima roxadustat memiliki kadar besi serum yang lebih stabil dibandingkan dengan epoetin alfa $(P=0.03){ }^{39}$ Sebuah studi melaporkan bahwa roxadustat dapat meningkatkan kadar transferin lebih baik dibandingkan dengan epoetin alfa (selisih perbedaan antar kelompok 0,43 $\pm 0,05$ $\mathrm{g} / \mathrm{L} ; 95 \%$ IK 0,32 - 0,53) serta dapat mempertahankan kadar besi serum lebih stabil dibandingkan dengan epoetin alfa (selisih perbedaan $25 \pm 4 \mathrm{~g} / \mathrm{dL} ; 95 \%$ IK 17 - 33). Pasien dalam kelompok epoetin alfa didapatkan penurunan kadar besi serum rata-rata, namun kadar TIBC tidak terjadi perubahan yang signifikan. ${ }^{33}$ Hasil penelitian ini sesuai dengan penelitian uji coba tahap 2 yang melaporkan kadar TIBC dan transferin meningkat secara signifikan $(\mathrm{P}<0,0001)$ pada kelompok roxadustat. Perbandingan kadar saturasi transferin antara kelompok yang menerima roxadustat dan kelompok yang menerima epoetin alfa tidak ditemukan berbeda yang signifikan. ${ }^{40}$

Berdasarkan kajian ini, adanya perbedaan rerata kadar besi serum antara roxadustat dan epoetin alfa pada pasien yang menjalani HD reguler diperoleh hasil signifikan secara statistik (WMD 5,02; 95\% IK: 3,65-6,40; $\mathrm{P}=0,00001)$. Penelitian meta-analisis lain juga menemukan kadar besi serum meningkat secara signifikan pada kelompok roxadustat dibanding epoetin alfa (SMD 0,39, 95\% IK: 0,23 $-0,55, \quad \mathrm{P}<0,00001) .{ }^{49} \quad$ Ditemukan juga perbandingan yang signifikan antara rerata transferin pada kelompok roxadustat dan epoetin alfa (WMD 67,88; $\mathrm{P}=0,0005 ; 95 \%$ IK: 29,86-105,90). Dua penelitian metaanalisis lainnya juga melaporkan kadar transferin meningkat secara signifikan pada kelompok roxadustat, dengan hasil pada masing-masing studi yaitu SMD 1,81; 95\% IK 1,53-2,08 ${ }^{43}$ dan SMD 0,36; 95\% IK: 0,28- 0,44, $\mathrm{P}<0,00001 .{ }^{49}$ Namun, perbandingan rerata feritin antara roxadustat dan epoetin alfa pada pasien yang menjalani HD reguler tidak diperoleh hasil signifikan secara statistik (WMD 1,63; $\mathrm{P}=0,94 ; 95 \% \mathrm{IK}:-39,14-42,40)$. Dua studi meta-analisis lainnya melaporkan kadar feritin berkurang secara signifikan pada kelompok roxadustat dibandingkan 


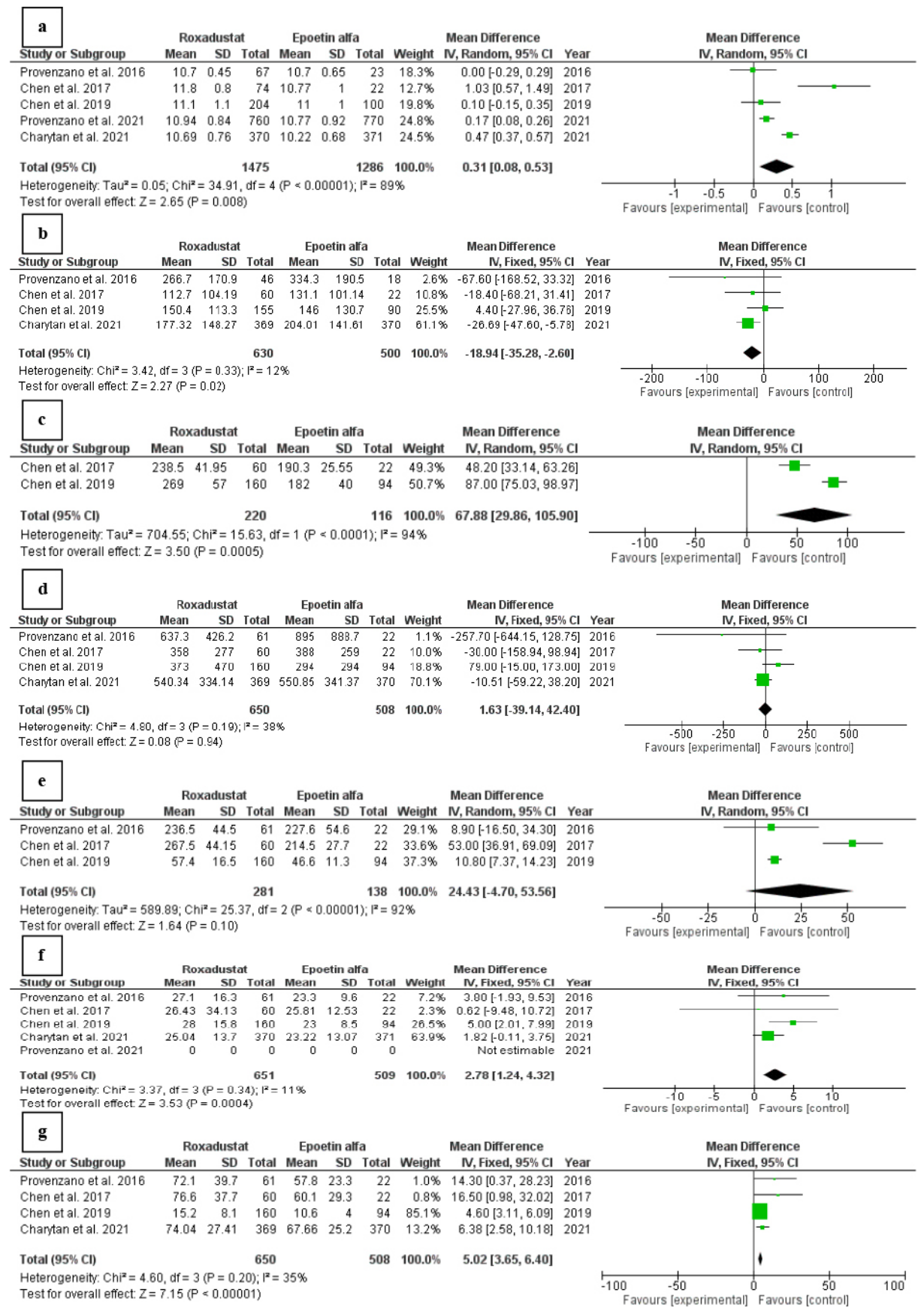

Gambar 4. Forest plot manajemen anemia antara roxadustat dan epoetin alfa pada pasien yang menjalani HD reguler. (a) $\mathrm{Hb}$, (b) hepsidin, (c) transferin, (d) feritin, (e) TIBC, (f) saturasi transferin, (g) besi serum.

dengan kelompok epoetin alfa, dengan hasil pada masing-masing studi yaitu SMD 0,02; 95\% IK -0,18-0,2 $1^{43}$ dan WMD $=-61.05,95 \%$ IK: 85.70 hingga 36.40, $\mathrm{P}<0.00001 .{ }^{44}$

Kami menemukan perbandingan rerata TIBC antara roxadustat dan epoetin alfa pada pasien yang menjalani HD reguler tidak signifikan secara statistik (WMD 24,43; P=0,10; 95\% IK: -4,70-
HD reguler diperoleh signifikan secara statistik (WMD 2,78; 95\% IK: 1,24- 4,32; $\mathrm{P}=0,0004)$. Hasil ini diperkuat dengan penelitian meta-analisis lainnya yang juga melaporkan saturasi transferin meningkat secara signifikan pada kelompok roxadustat dibandingkan dengan kelompok epoetin alfa $(\mathrm{MD}=6,09,95 \%$ IK: 5,36 - 6,82, $\mathrm{P}<0,0001){ }^{49}$ Penelitian terdahulu pada pasien yang menjalani HD reguler dengan anemia tanpa terapi besi intravena melaporkan bahwa kadar besi serum lebih rendah secara signifikan pada kelompok epoetin alfa jika dibandingkan pada kelompok roxadustat. ${ }^{48}$ Sebuah studi lainnya menyatakan bahwa anemia pada pasien yang menjalani HD reguler dengan roxadustat $40 \%$ lebih sedikit memerlukan terapi besi intravena bulanan serta 33\% lebih rendah dalam melakukan transfusi darah merah dibandingkan dengan epoetin alfa.

Berdasarkan hasil penelitian ini, roxadustat dapat mengurangi kebutuhan besi intravena dan transfusi darah, sekaligus mempertahankan kadar TIBC, transferin dan saturasi transferin yang sebanding dengan epoetin alfa. ${ }^{42}$ Hasil tersebut mendukung roxadustat sebagai agen stimulan eritropoiesis yang kuat sekaligus memberikan efek positif pada penyerapan dan mobilisasi zat besi. ${ }^{36}$ Roxadustat juga dapat mengurangi kebutuhan terapi besi intravena yang umumnya diperlukan dalam terapi ESA, sehingga roxadustat berpotensi membatasi paparan efek samping serta biaya dari pemberian terapi besi intravena. ${ }^{28}$ Umumnya, diperlukan ESA dosis tinggi untuk mempertahankan kadar $\mathrm{Hb}$ yang optimal, namun dosis tinggi ini dapat meningkatan risiko morbiditas dan mortalitas kardiovaskular. ${ }^{14-16,50}$

\section{Perbandingan Kadar $\mathrm{Hb}$}

Berdasarkan pada penelitian yang melibatkan 1.530 pasien yang menjalani HD reguler di Amerika Serikat melaporkan perubahan rata-rata kadar $\mathrm{Hb}$ setelah 6 minggu pengobatan yaitu pada kelompok roxadustat terjadi peningkatan sebesar 0,3 g/dL, sedangkan pada kelompok epoetin alfa terjadi penurunan sebesar $1,0 \mathrm{~g} /$ dL. ${ }^{40}$ Hasil yang sejalan ditemukan pada penelitian di Cina, dimana pengobatan roxadustat menghasilkan peningkatan 


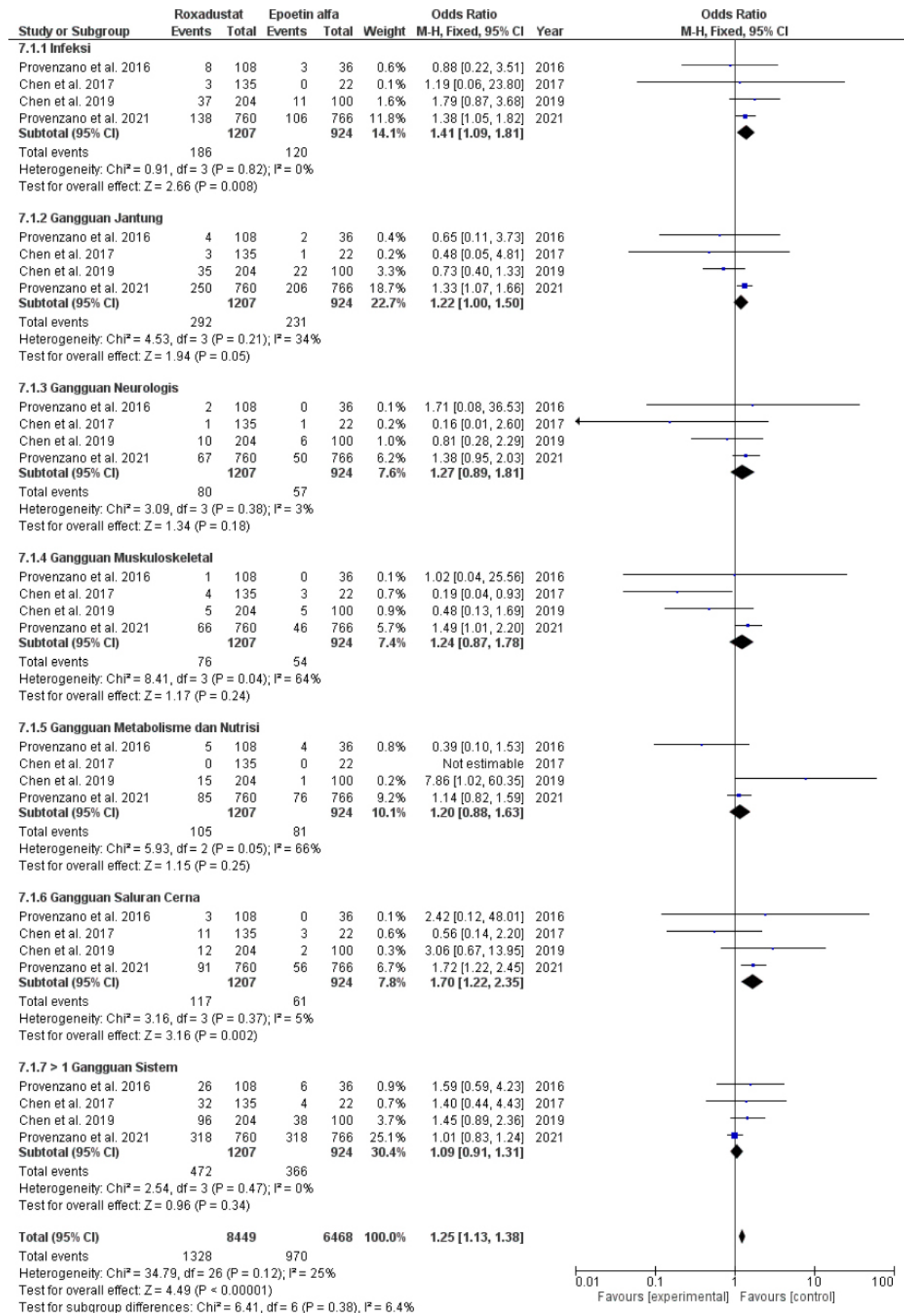

Gambar 5. Forest plot kejadian efek samping antara roxadustat dan epoetin alfa pada pasien yang menjalani HD reguler.

rata-rata $\mathrm{Hb}$ lebih besar, yaitu $0,7 \pm 1,1 \mathrm{~g} /$ $\mathrm{dL}$ dibandingkan pengobatan epoetin alfa $(0,5 \pm 1,0 \mathrm{~g} / \mathrm{dL}){ }^{33}$ Persentase pasien dengan rata-rata $\mathrm{Hb}$ sebesar $10,0 \mathrm{~g} /$ dl pada pengobatan roxadustat sebesar $66,1 \%(95 \%$ IK: $61,0-70,9)$ dan 58,6\% (95\% IK: 53,4 - 63,7) pada pengobatan dengan epoetin alfa (selisih perbedaan: 7,6\%; 95\% IK: 0,9 -14,3). Pasien dengan rata-rata $\mathrm{Hb}$ antara 10,0-12,0 g/dl adalah 64,1\% (95\% IK: 58,7 hingga 69,2) pada kelompok roxadustat dan $60,8 \%$ pada kelompok epoetin alfa (95\% IK: 55,5 65,9) (selisih perbedaan: 2,7\%; 95\% IK: 4,3 - 9,7). ${ }^{42}$ Penelitian lainnya membagi kelompok penelitian berdasarkan dosis roxadustat. Efek peningkatan kadar $\mathrm{Hb}$ pada pengobatan roxadustat dengan dosis
$1 \mathrm{mg} / \mathrm{kg}$ sebanding dengan efek epoetin alfa, sementara dosis $1,5 \mathrm{mg} / \mathrm{kg}$ roxadustat lebih efektif dalam meningkatkan kadar $\mathrm{Hb}$ dibandingkan dengan epoetin alfa. ${ }^{40}$ Hasil yang sejalan dilaporkan penelitian lain, dimana kelompok pasien yang menjalani HD reguler yang dapat mempertahankan kadar $\mathrm{Hb}$ normal lebih banyak ditemukan pada kelompok dosis menengah roxadustat $(\mathrm{P}=0,008)$ dan dosis tinggi epoetin alfa $(\mathrm{P}=0,0003){ }^{39}$ Kami memperoleh bahwa kadar $\mathrm{Hb}$ setelah pemberian terapi roxadustat lebih baik dibandingkan dengan epoetin alfa pada pasien yang menjalani HD reguler (WMD 0,31; $\mathrm{P}=0,008 ; 95 \%$ IK: 0,08- 0,53). Penelitian meta-analisis lain melaporkan kadar $\mathrm{Hb}$ meningkat secara signifikan pada kelompok roxadustat (WMD 1,57; 95\% IK 1,17-1,98). ${ }^{43}$ Hasil ini diperkuat dengan studi lain yang melaporkan adanya peningkatan $\mathrm{Hb}$ lebih baik secara signifikan (SMD 11,70, IK 95\%: 0,41 - 22,99, $\mathrm{P}=0,04)$ pada kelompok roxadustat dibandingkan epoetin alfa (OR 1,97, 95\% IK: 1,7 - 3,33, P=0,01). ${ }^{49}$ Seluruh studi yang dievaluasi pada kajian ini menunjukkan roxadustat sebanding dan bahkan lebih efektif dalam mencapai dan mempertahankan kadar $\mathrm{Hb}$ dibandingkan epoetin alfa pada pasien yang menjalani HD reguler.

\section{Efek samping dan keamanan}

Sebanyak $77,9 \%$ pasien anemia dengan pengobatan roxadustat dan $63,0 \%$ yang diobati dengan epoetin alfa dilaporkan memiliki minimal satu efek samping selama pengobatan. ${ }^{33}$ Dua penelitian lainnya menemukan hasil yang serupa, dimana perbedaan antar kelompok tidak berbeda jauh. ${ }^{41,42}$ Kejadian efek samping yang paling sering dilaporkan adalah infeksi saluran pernapasan atas, yang terjadi pada 37 pasien $(18,1 \%)$ pada kelompok roxadustat dan 11 pasien $(11,0 \%)$ pada kelompok epoetin alfa. ${ }^{+}$ Penelitian lain menemukan efek samping yang sering adalah mual, yang terjadi pada $17,0 \%$ pasien pada kelompok roxadustat dan 16,2\% pada kelompok epoetin alfa. Efek samping hipertensi terjadi pada $16,8 \%$ kelompok roxadustat dan 12,7\% kelompok epoetin alfa. ${ }^{42}$

Sebuah studi menyatakan perubahan rata-rata tekanan arteri dari awal hingga 
27 minggu pengobatan adalah $2,1 \mathrm{mmHg}$ pada kelompok roxadustat dan $0,7 \mathrm{mmHg}$ pada kelompok epoetin alfa (selisih perbedaan, 1,4 mmHg; 95\% IK 3,7 - 1,0). ${ }^{33}$ Hasil ini sejalan dengan penelitian lain yang menemukan perubahan rata-rata (SD) tekanan arteri selama pengobatan anemia pada kelompok roxadustat dan kelompok epoetin alfa adalah $0,05(9,00)$ mmHg dan $1,03(9,24) \mathrm{mmHg}$, dengan selisih perbedaan 0,35 ( $95 \%$ IK 1,65$0,95){ }^{41}$ Tetapi, sebuah penelitian uji klinis fase 3 yang dilakukan di Amerika Serikat menemukan tidak adanya perubahan baseline tekanan darah sistolik/diastolik yang berarti antara kelompok penelitian roxadustat dan epoetin alfa. ${ }^{42}$ Persentase pasien yang mengalami eksaserbasi hipertensi selama pengobatan pada kelompok roxadustat adalah $25,9 \%$ dan $25,4 \%$ pada kelompok epoetin alfa (Hazard Ratio (HR) 1,02; 95\% IK $0,84-1,25){ }^{41}$ Hasil ini sejalan dengan penelitian lainnya yang menyatakan perbandingan kejadian hipertensi antara kelompok perlakuan roxadustat dan epoetin alfa adalah $32,0 \%$ berbanding 32,0\% (HR 1,26; 95\% IK: 0,97$1,64 ; \mathrm{P}=0,08) .42$

Kejadian hiperkalemia dilaporkan lebih sering pada kelompok roxadustat dibandingkan kelompok epoetin alfa. Setelah minggu ke-5 pengobatan, terjadi perubahan kadar kalium sebesar 0,12 $\mathrm{mmol} / \mathrm{L}$ pada kelompok roxadustat dan 0,01 $\mathrm{mmol} / \mathrm{L}$ dalam kelompok epoetin alfa. ${ }^{33}$ Penelitian serupa juga melaporkan kejadian hiperkalemia lebih besar pada kelompok roxadustat dibandingkan kelompok epoetin alfa ( $16,2 \%$ dan $15,1 \%)$, walaupun dengan selisih yang tidak jauh berbeda. ${ }^{42}$ Sebanyak 29 pasien $(14,2 \%)$ diobati dengan roxadustat dan 10 pasien $(10,0 \%)$ diobati dengan epoetin alfa dilaporkan memiliki setidaknya satu efek samping yang fatal selama pengobatan..$^{33}$ Sebuah studi menyatakan persentase kejadian komplikasi fatal antar dua kelompok tidak jauh berbeda, yaitu 16,8\% pada kelompok roxadustat dibandingkan $15,7 \%$ pada kelompok epoetin alfa. ${ }^{42}$ Efek samping serius yang paling sering dilaporkan adalah komplikasi akses vaskular (oklusi fistula arteriovenosa, komplikasi fistula arteriovenosa, dan trombosis fistula arteriovenosa) yang terjadi pada proporsi yang sama pada kedua kelompok. ${ }^{33}$ Penelitian lainnya menilai risiko kardiovaskular pada kedua kelompok, dimana gangguan kardiovaskular lebih rendah pada kelompok roxadustat dibandingkan epoetin alfa (HR, 0,66; 95\% IK, 0,50 hingga 0,89; $\mathrm{P}=0,005) .{ }^{41}$ Namun, sebuah penelitian uji coba fase 2 tidak menemukan kejadian kardiovaskular pada kelompok roxadustat selama studi. ${ }^{39}$ Risiko stroke lebih rendah pada kelompok roxadustat dibandingkan epoetin alfa (HR 0,41; 95\% IK 0,18 hingga 0,$94 ; \mathrm{P}=0,035) .{ }^{41}$

Kami menemukan adanya risiko kejadian efek samping yang terjadi setelah pemberian terapi roxadustat dibandingkan dengan epoetin alfa $(\mathrm{OR}=1,25 ; 95 \%$ IK 1,13-1,38). Dua kajian meta-analisis lainnya melaporkan keamanan dan insiden efek samping pada kelompok roxadustat tidak jauh berbeda dibandingkan dengan epoetin alfa dengan hasil masing-masing studi yaitu Relative Risk/RR=0,99 (95\% IK $0,83-1,1 ; \mathrm{P}=0,89)^{43}$ dan $\mathrm{OR}=1.06(95 \%$ IK: $0.30-3.74, \quad \mathrm{P}=0.93) .^{49}$ Sebuah studi juga tidak menemukan hubungan yang signifikan antara roxadustat dan kejadian efek samping yang serius $R R=1,43$ (95\% IK $0,85-2,40){ }^{43}$

\section{KESIMPULAN}

Roxadustat lebih efektif mengobati anemia pada pasien yang menjalani HD reguler di bandingkan epoetin alfa. Roxadustat lebih baik dalam merangsang eritropoiesis, menurunkan kadar hepsidin, meningkatkan dan mempertahankan kadar $\mathrm{Hb}$, meningkatkan kadar besi serum, transferin, dan saturasi transferin. Perbandingan profil keamanan antara roxadustat dan epoetin alfa tidak jauh berbeda. Data-data hingga saat ini mendukung roxadustat sebagai alternatif pilihan terapi anemia pada pasien yang menjalani HD reguler.

\section{KONFLIK KEPENTINGAN}

Penulis menyatakan tidak terdapat konflik kepentingan dalam penulisan artikel ini.

\section{PENDANAAN}

Pendanaan dalam penulisan ditanggung sepenuhnya oleh penulis dan tidak memperoleh bantuan dari pihak manapun.

\section{KONTRIBUSI PENULIS}

Seluruh penulis memegang peranan dan berkontribusi dalam penyusunan dan penyuntingan artikel ini.

\section{DAFTAR PUSTAKA}

1. Control UC for Diseases. National Chronic Kidney Disease Fact Sheet. CDC. Published 2014. Accessed June 18, 2021. http://www.cdc. gov/diabetes/pubs/pdf/kidney_factsheet.pdf

2. Hemmelgarn BR, Zhang J, Manns BJ, et al. Progression of kidney dysfunction in the community-dwelling elderly. Kidney Int. 2006;69(12):2155-2161. doi:10.1038/ sj.ki.5000270

3. Roderick PJ, Atkins RJ, Smeeth L, et al. Detecting chronic kidney disease in older people; what are the implications? Age Ageing. 2008;37(2):179186. doi:10.1093/ageing/afm180

4. Dipiro JT. Pharmacoterapy Handbook 9th Edition. Mc Graw Hill; 2015.

5. Suyatno FE, Rotty LWA, Moeis ES. Gambaran anemia defisiensi besi pada pasien penyakit ginjal kronik stadium $\mathrm{V}$ yang menjalani hemodialisis di instalasi tindakan hemodialisis RSUP PROF. DR. R.D. Kandou Manado. e-CliniC. 2016;4(1). doi:10.35790/ ecl.4.1.2016.10948

6. McClellan W, Aronoff SL, Bolton WK, et al. The prevalence of anemia in patients with chronic kidney disease. Curr Med Res Opin. 2004;20(9):1501-1510. doi:10.1185/030079904x2763

7. Guralnik JM, Eisenstaedt RS, Ferrucci L, Klein HG, Woodman RC. Prevalence of anemia in persons 65 years and older in the United States: evidence for a high rate of unexplained anemia. Blood. 2004;104(8):2263-2268. doi:10.1182/ blood-2004-05-1812

8. Adiatma D, Tobing M. Prevalensi Dan Jenis Anemia Pada Pasien Penyakit Ginjal Kronik Yang Menjalani Hemodialisis Reguler (Studi Di Rsup Dr. Kariadi Semarang). J Kedokt Diponegoro. 2014;3(1):137839.

9. Collins AJ. The hemoglobin link to adverse outcomes. Adv Stud Med. 2003;3:194-197.

10. McClellan WM, Flanders WD, Langston RD, Jurkovitz C, Presley R. Anemia and Renal Insufficiency Are Independent Risk Factors for Death among Patients with Congestive Heart Failure Admitted to Community Hospitals: A Population-Based Study. J Am Soc Nephrol. 2002;13(7):1928-1936. doi:10.1097/01. asn.0000018409.45834.fa

11. Sarnak MJ, Tighiouart H, Manjunath G, et al. Anemia as a risk factor for cardiovascular disease in the atherosclerosis risk in communities (aric) study. J Am Coll Cardiol. 2002;40(1):27-33. doi:10.1016/s0735-1097(02)01938-1

12. Kidney Disease: Improving Global Outcomes (KDIGO) Anemia Work Group. KDIGO Clinical Practice Guideline for Anemia in Chronic Kidney Disease. Kidney Int Suppl. 2012;2(4):279-335. doi:10.1038/kisup.2012.40

13. Gill KS, Muntner P, Lafayette RA, et al. Red blood cell transfusion use in patients with 
chronic kidney disease. Nephrol Dial Transplant. 2013;28(6):1504-1515. doi:10.1093/ndt/gfs580

14. Besarab A, Bolton WK, Browne JK, et al. The Effects of Normal as Compared with Low Hematocrit Values in Patients with Cardiac Disease Who Are Receiving Hemodialysis and Epoetin. N Engl J Med. 1998;339(9):584-590. doi:10.1056/nejm199808273390903

15. Singh AK, Szczech L, Tang KL, et al. Correction of Anemia with Epoetin Alfa in Chronic Kidney Disease. N Engl J Med. 2006;355(20):2085-2098. doi:10.1056/nejmoa065485

16. Drüeke TB, Locatelli $\mathrm{F}$, Clyne $\mathrm{N}$, et al. Normalization of Hemoglobin Level in Patients with Chronic Kidney Disease and Anemia. $N$ Engl J Med. 2006;355(20):2071-2084. doi:10.1056/nejmoa062276

17. Pfeffer MA, Burdmann EA, Chen C-Y, et al. A Trial of Darbepoetin Alfa in Type 2 Diabetes and Chronic Kidney Disease. $N$ Engl J Med. 2009;361(21):2019-2032. doi:10.1056/ nejmoa 0907845

18. Szczech LA, Barnhart HX, Inrig JK, et al. Secondary analysis of the CHOIR trial epoetin- $\alpha$ dose and achieved hemoglobin outcomes. Kidney Int. 2008;74(6):791-798. doi:10.1038/ki.2008.295

19. Zhang Y, Thamer M, Stefanik K, Kaufman J, Cotter DJ. Epoetin requirements predict mortality in hemodialysis patients. Am J Kidney Dis. 2004;44(5):866-876. doi:10.1016/s02726386(04)01086-8

20. Koury MJ, Haase VH. Anaemia in kidney disease: harnessing hypoxia responses for therapy. Nat Rev Nephrol. 2015;11(7):394-410. doi:10.1038/nrneph.2015.82

21. Suttorp MM, Hoekstra T, Mittelman M, et al. Treatment with high dose of erythropoiesisstimulating agents and mortality: analysis with a sequential Cox approach and a marginal structural model. Pharmacoepidemiol Drug Saf. 2015;24(10):1068-1075. doi:10.1002/pds.3855

22. Busti F, Marchi G, Ugolini S, Castagna A, Girelli D. Anemia and Iron Deficiency in Cancer Patients: Role of Iron Replacement Therapy. Pharmaceuticals. 2018;11(4):94. doi:10.3390/ ph11040094

23. Ratcliffe LEK, Thomas W, Glen J, et al. Diagnosis and Management of Iron Deficiency in CKD: A Summary of the NICE Guideline Recommendations and Their Rationale. Am J Kidney Dis. 2016;67(4):548-558. doi:10.1053/j. ajkd.2015.11.012

24. Kaelin WG, Ratcliffe PJ. Oxygen Sensing by Metazoans: The Central Role of the HIF Hydroxylase Pathway. Mol Cell. 2008;30(4):393402. doi:10.1016/j.molcel.2008.04.009

25. Semenza GL, Agani F, Booth G, et al. Structural and functional analysis of hypoxia-inducible factor 1. Kidney Int. 1997;51(2):553-555. doi:10.1038/ki.1997.77

26. Peyssonnaux C, Nizet V, Johnson RS. Role of the hypoxia inducible factors HIF in iron metabolism. Cell Cycle. 2008;7(1):28-32. doi:10.4161/cc.7.1.5145

27. Ganz T. Hepcidin, a key regulator of iron metabolism and mediator of anemia of inflammation. Blood. 2003;102(3):783-788. doi:10.1182/blood-2003-03-0672
28. Atanasiu V, Manolescu B, Stoian I. Hepcidin? central regulator of iron metabolism. Eur $J$ Haematol. 2007;78(1):1-10. doi:10.1111/j.16000609.2006.00772.x

29. Nemeth E, Ganz T. Regulation of Iron Metabolism by Hepcidin. Annu Rev Nutr. 2006;26(1):323-342. doi:10.1146/annurev. nutr.26.061505.111303

30. Bernhardt WM, Câmpean V, Kany S, et al. Preconditional Activation of Hypoxia-Inducible Factors Ameliorates Ischemic Acute Renal Failure. J Am Soc Nephrol. 2006;17(7):19701978. doi:10.1681/asn.2005121302

31. Akizawa T, Iwasaki M, Yamaguchi Y, Majikawa Y, Reusch M. Phase 3, Randomized, DoubleBlind, Active-Comparator (Darbepoetin Alfa) Study of Oral Roxadustat in CKD Patients with Anemia on Hemodialysis in Japan. J Am Soc Nephrol. 2020;31(7):1628-1639. doi:10.1681/ asn.2019060623

32. Akizawa T, Ueno M, Shiga T, Reusch M. Oral roxadustat three times weekly in ESA-naïve and ESA-converted patients with anemia of chronic kidney disease on hemodialysis: Results from two phase 3 studies. Ther Apher Dial. 2020;24(6):628-641. doi:10.1111/17449987.13468

33. Chen N, Hao C, Liu B-C, et al. Roxadustat Treatment for Anemia in Patients Undergoing Long-Term Dialysis. $N$ Engl $J$ Med. 2019;381(11):1011-1022. doi:10.1056/ nejmoa1901713

34. Besarab A, Chernyavskaya E, Motylev I, et al. Roxadustat (FG-4592): Correction of Anemia in Incident Dialysis Patients. J Am Soc Nephrol. 2015;27(4):1225-1233. doi:10.1681/ asn.2015030241

35. Nangaku N, Kojima I, Tanaka T, Ohse T, Kato H, Fujita F. Novel Drugs and the Response to Hypoxia: HIF Stabilizers and Prolyl Hydroxylase. Recent Pat Cardiovasc Drug Discov. 2006;1(2):129-139. doi:10.2174/157489006777442522

36. Besarab A, Provenzano R, Hertel J, et al. Randomized placebo-controlled dose-ranging and pharmacodynamics study of roxadustat (FG-4592) to treat anemia in nondialysisdependent chronic kidney disease (NDDCKD) patients. Nephrol Dial Transplant. 2015;30(10):1665-1673. doi:10.1093/ndt/ gfv302

37. Provenzano R, Besarab A, Sun $\mathrm{CH}$, et al. Oral Hypoxia-Inducible Factor Prolyl Hydroxylase Inhibitor Roxadustat (FG-4592) for the Treatment of Anemia in Patients with CKD. Clin J Am Soc Nephrol. 2016;11(6):982-991. doi:10.2215/cjn.06890615

38. Green S, Higgins JPT. Preparing a Cochrane Review. Cochrane Handb Syst Rev Interv.:11-30. doi:10.1002/9780470712184.ch2

39. Chen N, Qian J, Chen J, et al. Phase 2 studies of oral hypoxia-inducible factor prolyl hydroxylase inhibitor FG-4592 for treatment of anemia in China. Nephrol Dial Transplant. 2017;32(8):1373-1386. doi:10.1093/ndt/gfx011

40. Provenzano R, Besarab A, Wright S, et al. Roxadustat (FG-4592) versus epoetin alfa for anemia in patients receiving maintenance hemodialysis: A phase 2, randomized, 6- to 19-week, open-label, active-comparator, dose-ranging, safety and exploratory efficacy study. Am J Kidney Dis. 2016;67(6):912-924. doi:10.1053/j.ajkd.2015.12.020

41. Provenzano R, Fishbane S, Szczech L, et al. Pooled Analysis of Roxadustat for Anemia in Patients With Kidney Failure Incident to Dialysis. Kidney Int Reports. 2021;6(3):613-623. doi:10.1016/j.ekir.2020.12.018

42. Charytan C, Manllo-Karim R, Martin ER, et al. A Randomized Trial of Roxadustat in Anemia of Kidney Failure: SIERRAS Study. Kidney Int Reports. Published online 2021. doi:10.1016/j. ekir.2021.04.007

43. Zheng Q, Yang H, Fu X, et al. The efficacy and safety of roxadustat for anemia in patients with chronic kidney disease: a meta-analysis. Nephrol Dial Transplant. Published online 2020. doi:10.1093/ndt/gfaal10

44. Jia L, Dong $\mathrm{X}$, Yang J, Jia $\mathrm{R}$, Zhang $\mathrm{H}$. Effectiveness of hypoxia-inducible factor prolyl hydroxylase inhibitor roxadustat on renal anemia in non-dialysis-dependent chronic kidney disease: a systematic review and metaanalysis. Ann Transl Med. 2019;7(23):720. doi:10.21037/atm.2019.12.18

45. Provenzano R, Goodkin D, Klaus S, et al. 253 Evaluation of FG-4592, a Novel Oral HypoxiaInducible Factor Prolyl Hydroxylase Inhibitor, to Treat Anemia in Hemodialysis Patients. Am J Kidney Dis. 2011;57(4):B80. doi:10.1053/j. ajkd.2011.02.256

46. Bailie GR, Larkina M, Goodkin DA, et al. Data from the Dialysis Outcomes and Practice Patterns Study validate an association between high intravenous iron doses and mortality. Kidney Int. 2015;87(1):162-168. doi:10.1038/ ki.2014.275

47. Karaboyas A, Zee J, Morgenstern H, et al. Understanding the Recent Increase in Ferritin Levels in United States Dialysis Patients: Potential Impact of Changes in Intravenous Iron and Erythropoiesis-Stimulating Agent Dosing. Clin J Am Soc Nephrol. 2015;10(10):1814-1821. doi:10.2215/cjn.02600315

48. Macdougall IC, Tucker B, Thompson J, Tomson CR V, Baker LRI, Raine AEG. A randomized controlled study of iron supplementation in patients treated with erythropoietin. Kidney Int. 1996;50(5):1694-1699. doi:10.1038/ki.1996.487

49. Wang H, Huang K, Wang C, Chen C, Fang H, Cao J. Effectiveness and safety of roxadustat in the treatment of anemia of kidney disease: a systematic review and meta-analysis. Ann Palliat Med. 2021;10(4):4736-4746. doi:10.21037/apm21-456

50. Pfeffer MA, Burdmann EA, Chen C-Y, et al. Baseline Characteristics in the Trial to Reduce Cardiovascular Events With Aranesp Therapy (TREAT). Am J Kidney Dis. 2009;54(1):59-69. doi:10.1053/j.ajkd.2009.04.008

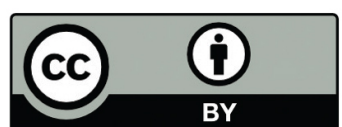

This work is licensed under a Creative Commons Attribution 